Elise Naumann

\title{
Food, Everyday Practice, and the Self in Medieval Oslo: A Study of Identities Based on Dietary Reconstructions from Human Remains
}

\begin{abstract}
The significance of everyday practice, including food-related activities, is becoming increasingly acknowledged in archaeological research. Even so, studies of food and meals are seldom included as an integrated and essential aspect to understand political organization and development. In this article, the complex relation between human agency, the construction of the self, and political organization is discussed with everyday activities related to food as the point of departure. The discussion is based on results from osteological and dietary analyses of human individuals buried in medieval Oslo, enabling a reconstruction of dietary and nutritional development in lived lives. Human experience is considered as part of, and contributor to, societal structure and change in the early medieval town of Oslo.
\end{abstract}

Keywords: food, everyday practice, medieval Oslo, social memory, human remains, dietary reconstruction, isotope analyses

\section{Introduction - Food and the Self}

It is sometimes easy to forget that, beyond the lives of the royal and ecclesiastical elite, medieval towns consisted primarily of ordinary people doing fundamentally ordinary things. Each individual within a town contributed to its structure and development, acting in response to societal circumstances, but also sometimes actively asserting the individual and perceptions of the self - each person acting in line with their personal and communal experiences. How did the self play a role in the structure and development of the town? Drawing on archaeological and osteological sources from the medieval town of Oslo, this article aims to add a piece to this complex puzzle by focusing on that which is most ordinary: food, and the multitude of actions, emotions, and meanings provoked by, connected to, and derived from the relationship between food and the self.

Elise Naumann, Norwegian Institute for Cultural Heritage

Ә Open Access. (c) 2020 Elise Naumann, published by De Gruyter. (cc) BY-NC-ND This work is licensed under a Creative Commons Attribution-NonCommercial-NoDerivatives 4.0 International License.

https://doi.org/10.1515/9783110655582-011 
The significance of food in human culture is well established in anthropological studies (Goody 1982; Douglas and Isherwood 1996; Lupton 1996; Lévi-Strauss 1966; Rozin 1987, 1976). Not only is food essential to survival and health, but the range of social practices connected with food - procurement, storage, preparation, and the meal itself - are deeply rooted in human culture. These practices are important elements in the negotiations that occur between identity, social position, and social organization. Given the repetitive nature of everyday food-related practices and the volume of resources associated with them, food ought to be considered a key factor in studies of human societies in the past.

Although the significance of food has made its way into recent social archaeology research (Hastorf 2017; Hamilakis 2011; Schrader 2019; Bukkemoen 2016), the archaeology of food is seldom a focus of studies of past societies. Instead, food practice is often applied as a separate approach, or given minor attention, as seen in earlier studies of medieval Oslo discussing the urbanization process, political organization and economic development (see for instance Molaug 2008, Helle 2006 and Schia 1991). However, some new scholarship has drawn attention to food strategies and food culture in Oslo through analyses of archaeological, paleo-botanical, and osteological materials (Sture and Bauer 2017; Vedeler 2017; Norseng 2015).

For the population of Oslo, food was undoubtedly integral to most aspects of daily life, related to issues of social interaction, leisure activities, satisfaction, endeavors, and sensory and emotional experiences (taste, smell, hunger, disgust, envy, and desire). Thus, food and its associated roles formed an essential part of the makeup of people's day-to-day routines. The selection of food was determined by cultural and individual preferences, a person's position with the hierarchical structure, as well as availability. Food preparation included a range of tools, equipment, and skills, and the sharing of meals contributed to the formation of different social relations. From dawn to dusk, through the seasons of the year, in the town's narrow streets and open market places, around the home's hearth or table, in the barn, in the field, or at sea, people were involved in different activities centered around food. Through these various pursuits, which evoke emotions and contribute to memory production, food played a central role in the continuous negotiations between society and the self.

This paper investigates the role of food in this interplay between society and the self during the period of early urbanization in medieval Oslo. Current knowledge of food practice in medieval Oslo based on archaeology, literature, and anthropology will be considered together with dietary information derived from the remains of individuals buried in Oslo in the tenth to twelfth centuries. Through an understanding of food as a key factor in identity construction, this paper 
hopes to shed light on how practices related to food affected the development of social structures and the construction of personal identity in medieval Oslo.

\section{Food as Identity Marker through Practice and Memory}

The construction of identity - here understood as how a person or a group defines themselves and others in relation to other persons or groups - is dynamic by nature, a continuous and fluid process shaped by experience on both a personal and communal level (Meskell 1999, 2001). Identity is multilayered; all people simultaneously have a number of different social identities that shift with different social relations, roles, and experiences. Identity operates on different levels: the broader level is defined by shared perceptions within a society or a group, through social organizations and structures, while a more exclusive and singular level of identity is formed through personal experiences. The latter level is more dynamic, as this form of identity is more exposed to immediate change and influence. These levels are not parallel entities, but are in constant reciprocal negotiation; individual experience and self-perception will affect the construction of group identity, which will at any time define individual identity (Meskell 2001). Because collective, shared identities within a group are more persistent, the commitment to communal identities should be considered in relation to social structures and the distribution of power (Gardner 2011). This dynamic is highly relevant to the discussion below regarding how and why any given person, through shifting and multilayered identities and variable life experiences, is still committed to certain overarching self-perceptions within a life span.

Being both fluid and fixed at the same time, identity is closely related to the production and maintenance of memory. Memory is not a ready-made bank of information from which anything from the past can be withdrawn; instead, it is a dynamic process of selection, modified in response to social organization and life experiences (Jones 2007). Because there is no way of remembering everything, memory construction involves both intentional and unintentional forgetting. Memory, as identity, is formed in different levels of shared and individual experience. The collective reconstruction "of the past in the past" is actively used to shape social memory (Van Dyke and Alcock 2003; Halbwachs 1992), though memory production also occurs as a result of semi-intentional and unintentional constructions in everyday practice (Cipolla 2008). Memory is created, shaped, maintained, and developed in negotiations between the individual and her interactions with her surroundings, through, for instance, material 
culture, written texts, sensory experiences, including smell and taste, or emotional responses to experiences. Especially relevant here is the relationship between memory and identity construction through day-to-day experiences related to food: this relationship will form the backdrop to a discussion of how the self is formed and renegotiated.

Along with many other elements of everyday life, food has long been a neglected focus of research on past societies, perhaps because it seems too ordinary and mundane to warrant much reflection (Hastorf 2017). However, as the groundbreaking works of anthropologists Claude Lévi-Strauss (1966) and Mary Douglas (1996) have established, there can be little doubt about the dynamic relation between identity construction and food culture. Food holds a significant position in memory production, activating all five senses at once (Hastorf 2017; Barker 1982). Through taste, smell, sight, sound, and touch, food preparation and consumption constitute an embodied form of memory. Taste is closely related to habit and repetition. Psychologist Paul Rozin (1987) suggests that individual experience is a determining factor for human food preferences - more so than age, gender, and biological variables. Because people tend to prefer familiar foods and are hesitant to try new ones, unfamiliar foods are commonly introduced together with known ones (Rozin 1987). The introduction of new foods can often be seen as a response to biological requirements: people need to consume a varied diet, and in times of shortages, for example, they need to supplement their diet. Rozin refers to the incongruity between the conservative nature of human food preferences and the need to explore new foods as the "omnivore paradox"; this leads to a more diverse diet than is biologically necessary (Rozin 1976). Of course, food selection and taste are also naturally affected by the presence of hierarchical structures and social control. In any hierarchical society, regulating and distributing common goods is an essential part of negotiating and maintaining power (Appadurai 1986).

The actual consumption of edibles is only one part of identity construction in the everyday practices associated with food. A range of activities are involved, including tending fields and gardens, constructing homes and spaces for cooking and eating, caring for animals, making and repairing tools, and participating in market exchanges, and these all contribute to the forming of both communal and individual identities. Each of these activities requires time, knowledge, and an engagement with surrounding resources and people. Tending a garden, for example, first requires a selection of seeds and fertile soil, followed by regular watering, weeding, protecting the produce from potential exploiters and, eventually, harvesting; these actions take place on a regular basis, integrated into everyday practice, and they occur before any actual preparation or consumption of the food. After harvesting, the products would have been distributed - 
possibly sold at market, shared between the members of the family, or offered to guests or other persons holding a special claim to the produced food. The preparation of food depends on skills and transferred knowledge, in addition to the handling of a variety of tools and equipment. The meal itself, the byproduct of a long chain of actions, would unlikely be the result of a random choice of place, time, and combination of people, but would be a quotidian event imbued with meaning - both reflecting and forming social relations and identities within daily life.

Against this backdrop, this paper will consider the relationship between identity construction and food in everyday practice. Furthermore, this relationship will be examined in connection with the dynamic process forming communal and individual identities. And lastly, these issues will be considered together with the power structures and individual human agency within the medieval town of Oslo.

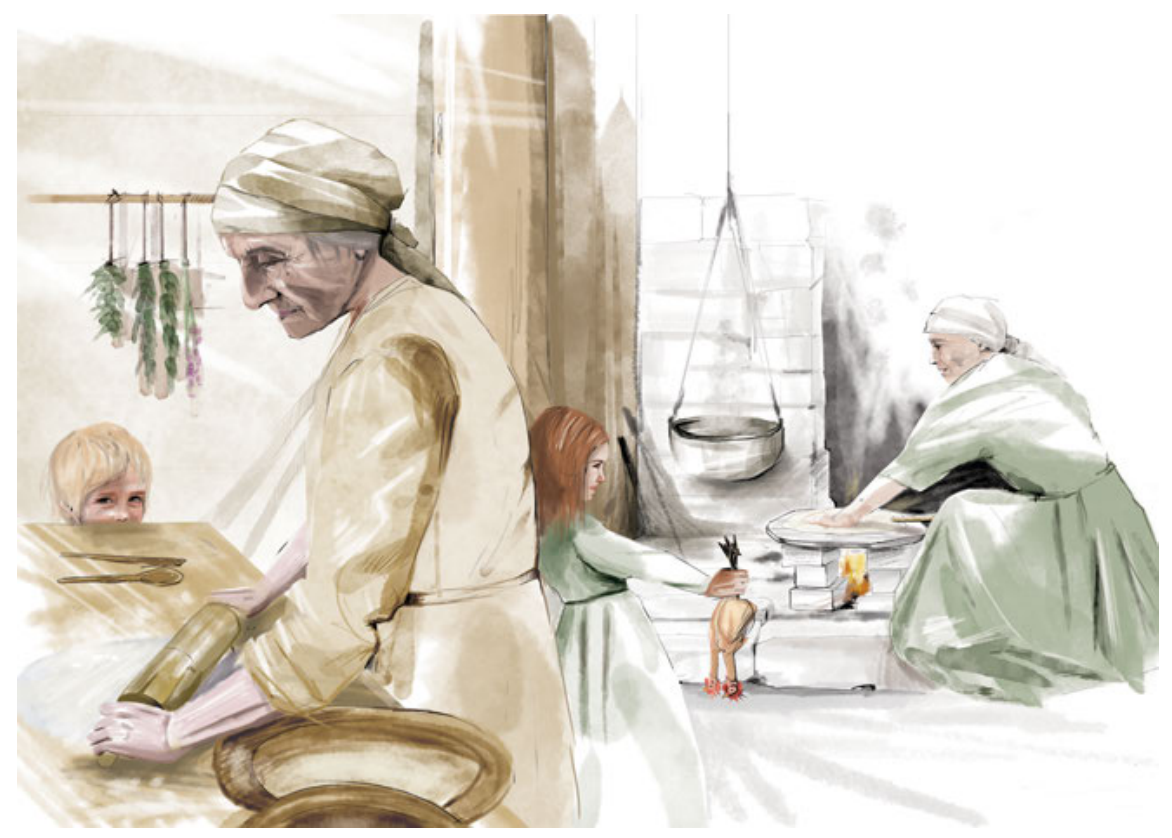

Fig. 1: Memory and identity construction are produced through day-to-day experiences related to food. For instance, food preparation forms the basis for social relations and interactions as well as the production and transference of knowledge; and these occur together with embodied sensorial and emotional experiences. (Illustration: Hege Vatnaland. Copyright: NIKU). 


\section{Food in Medieval Oslo AD 1000-1200}

As Christine A. Hastorf (2017) points out, many aspects of past food practices are today lost to us, including cooking aromas, how food was served, or the sounds of conversation and laughter among those sharing a meal. However, substantial amounts of extant material bear witness to past food practices, such as tools for plant cultivation and animal husbandry, cooking and eating equipment and utensils, animal bones, seeds, and shells. In addition, accounts in written sources as well as information embedded in chemical signatures in human bones provide evidence about past food customs of medieval Oslo.

The first signs of early urbanization in Oslo are dated to the first half of the eleventh century (Nordeide and Gulliksen 2007; Molaug 2008), though several farms from earlier periods have been identified in the Oslo region (Holmsen 1963). In general terms, one can say that the establishment of the early medieval towns in Norway concurs with the conversion from paganism to Christianity, though this is obviously a simplified statement; conversion started during the Viking Age and was a long and complicated process (Nordeide and Gulliksen 2007). However, current knowledge of the origins of Oslo is based partly on the oldest Christian graveyard in the area, believed to have been established in the first half of the eleventh century, clearly indicating a Christian burial tradition from the beginning of urban settlement. During the first generation of this expanding town development, the settlers experienced an increase in population, together with a more pronounced royal and ecclesiastical presence. The town's economy seems to have been dependent on supplemental resources from the surrounding agricultural areas (Helle 2006).

Oslo is situated in a rich agricultural region, with arable lands and access to marine sources; additionally, large and small game live in the surrounding woods. Even though a range of foods, from livestock, crops, small and large game, various marine species including fish, fruits, and vegetables were available in Oslo (Sture and Bauer 2017; Hufthammer 2015; Øye 1998; Griffin 1988), both written and archaeological sources indicate that barley and herring dominated the diets of most people (Øye 1998; Dybdahl 2000). Regarding livestock, both archaeological and written sources suggest cattle to be most common (Lie 1979; Hufthammer 2015; Skaar 2014), though remains from sheep and pigs are also regularly found (Hufthammer 2015; Lie 1979). Undoubtedly, though, the different foods available in the town were distributed unequally between people of different social rank (Skaar 2014; Sture and Bauer 2017; Øye 1998).

While there seems to have been a preference for meat in pre-medieval times, abstinence and fasting were parts of an ideal introduced with Christianity (Skaar 2014), with prohibitions against the eating of horse, dog, and cat established, 
punishable by law. Purity and redemption were closely associated with an ascetic lifestyle. This ideal, however, may not have been easily accepted and implemented in everyday customs, for a number of laws address restrictions and punishments for meat consumption, which may be evidence of an ongoing struggle between the Church and the community (Skaar 2014). It has been suggested that the introduction of fasting - the banning of meat consumption for more than one hundred days each year - led to an increase in the consumption of fish and shellfish (Skaar 2014). This assumption is particularly interesting in terms of dietary habits in towns, as the first urban settlements have been interpreted as "ports of faith," the first Christian settlements in Norway from which the new religion spread to the rest of the country (Nordeide 2011).

\section{Individual Food Practices in Oslo}

Within this general framework regarding food culture and the access to food in the medieval town of Oslo, the inhabitants were at any given time involved in different activities related to food, drawing upon opportunities, knowledge, and individual experience. How was food then incorporated into the daily organization for each person? Even though we can never fully understand this complex picture, we do have access to the human remains of certain individuals who most probably lived, and certainly were buried, within the medieval Oslo urban settlement. And while the information provided by human remains is often very practical in nature, it can nonetheless be employed in attempts to reveal complex patterns of social identity (Pearson and Meskell 2015; Schrader 2019).

Bioarchaeology also allows investigations into the early years of those who survived past their youth; both physical traits and isotopic values in teeth, for instance, may reveal periods of stress, malnutrition, and illness during childhood and early adolescence (Martin, Harrod, and Péres 2013; White, Black, and Folkens 2012). They can also provide information about dietary composition, dietary change, and geographic movement experienced during the time of tooth formation (Sealy, Armstrong, and Schrire 1995; Pollard and Heron 2008). Additionally, isotopic values in bones continuously change and reflect dietary habits during the last phases of life (Sealy, Armstrong, and Schrire 1995), while healed injuries, illness, and trauma experienced earlier in life may leave permanent marks on the bones. Stable isotope values of collagen in human remains provide information about the main protein components in the diet - differentiating between marine and terrestrial foods and between vegetable and animal products (Pollard and Heron 2008; Chisholm, Nelson, and Schwarcz 1982). The values in human tissue thus represent the average values from thousands of 
meals, consumed on a daily basis. Samples from different body tissue and teeth offer information from different stages of life - lived experience and embodied memory production throughout a period of changing identity. Food was a significant part of the lives of those buried in Oslo, and the results from the isotopic values offer a window into these lived experiences.

Information regarding the diets and food practices of individuals can significantly contribute to our understanding of past societies - not only what these people ate, but also how they ate, how food distribution and consumption was implemented in everyday life, how political organization defined access to food, how trade, agriculture, and animal husbandry were organized and controlled, and, finally, how family, work, gender, age, or other ethnic identity contributed to defining individual consumption behaviors. Thus, dietary reconstructions actually represent an embodied, and unbiased, human experience that archaeologists can make use of as a means to investigate lives, day-to-day experiences, and the social reality for individuals within the societies we endeavor to understand (Schrader 2019).

In a recent study, 20 individuals buried during the first centuries of urban Oslo were analyzed for stable isotopes $\left({ }^{13} \mathrm{C}\right.$ and $\left.{ }^{15} \mathrm{~N}\right)$ and strontium, enabling both a dietary reconstruction and a discussion of place of origin for the analysed individuals (Naumann et al. 2019): see Appendix 1 in this article. The stable isotope analyses applied facilitate a general estimation of primary protein sources, distinguishing between land-based plants, animals, and marine species (Naumann et al. 2019). The analyzed pool consisted of 11 women, 7 men, and 2 persons of unknown sex, ranging in age from approximately 13 to +60 at time of death. All 20 were buried in Oslo's earliest known graveyard, in the grounds of St. Clement's Church (Eide 1974), which later possibly functioned as a parish church (Nordeide and Gulliksen 2007; Naumann et al. 2019). The analyzed individuals might therefore represent people who lived within the urban settlement, as well as people who belonged to surrounding farms that were part of the extended urban environment. The sex-determined population buried at St. Clement's is slightly biased towards women (488 females and 414 males) (Holck and Kvaal 2000), suggesting that they are not necessarily demographically representative (Eide 1974). The strontium results from the 20 analyzed individuals indicate that these people were likely from the Oslo region, living within or in connection to the urban center. Most had a varied diet consisting of foods from both land and sea, and all seem to have eaten a certain amount of animal products (though not necessarily meat; the method does not allow for a separation between meat and other products such as milk or eggs) and possibly freshwater fish.

Furthermore, and of special interest to the present article, the lack of change in values suggests that most of the analyzed individuals did not significantly alter their diet throughout their lifetime. As similar isotopic values in humans 
might reflect different foods with the same isotopic values, a short discussion of these results seems necessary at this point. The stable isotope analyses performed on the human remains in question represent a fairly general source of information of different food types, and do not separate between, for instance, different animal products such as dairy and meat. This means that a person might well have consumed more meat and fewer dairy products in different stages of life, without any visible change in isotopic values. The same can be stated about a number of different plants and animals that are fundamentally different in terms of availability, value, and taste, but which leave isotopic values in human tissue that are inseparable. In short, for this group, we can conclude that most or all of them consumed a varied diet consisting of fish, terrestrial plants, and probably also terrestrial animals, but based on our current knowledge we are unable to reconstruct dietary components in more detail. The lack of significant change in isotopic values for each person throughout their lifetime might not represent actual dietary consistency, though given the pattern of unchanged isotopic values for most of the individuals in the study, a lack of dietary change seems to be the most plausible explanation, as this finding is unlikely coincidental.

The isotopic results do not reflect any trend of increased marine consumption, either throughout a single individual's lifetime or between generations (Naumann et al. 2019). This is confirmed by dietary results from individuals buried in Oslo in the late-medieval period, suggesting that people consumed the same amount of fish at that time as they did during the first generations of urban settlement (Jensen 2018). These results contrast with findings from a medieval population in Stavanger, which indicate an increase in marine consumption in medieval Stavanger (van der Sluis et al. 2016). The lack of increased marine consumption in the Oslo population suggests that the many fasting days introduced by the Church did not result in any actual decrease in meat consumption - indicating a resistance in the population to following the Christian regulations.

There was certainly variation between individuals - there is disparity in the diets of the 20 people that were analyzed (Naumann et al. 2019) - but each person seems to have consumed more or less the same composition or mix of foods from early childhood up until the time of death. These results contrast sharply with individual dietary variations during the Viking Age in northern Norway, where a change in diet, sometimes radical, over a lifetime seems to have been more common than dietary continuity (Naumann et al. 2014; Naumann, Price, and Richards 2014).

At first glance, the results from Oslo may seem trivial. After all, who would be surprised that people continued to eat the same types of food? But taking a closer look, these data are significant in several ways. First, as this is a definitive trend among the analyzed individuals, the results can hardly be construed 
as coincidental. Instead, the lack of dietary change represents a certain, specific trend within medieval Oslo. This trend shows that during a period of urban growth, Christianization, settlement expansion, and a shift in political organization, these inhabitants continued to eat the same types of food. This observation can be further developed, with the implication being that, over time, the population replicated not only their eating habits, but also a number of other activities related to the procurement, production, and preparation of these specific foods. Second, the results are also epistemologically significant. As small children, none of these persons could have prepared the food that they consumed. Others did this work for them, and in doing so, they also took all the necessary steps to ensure that these specific meals were served to this child. Later on, our study population may or may not have been involved in the procurement and preparation of the food for their own meals, but the knowledge involved was certainly carried on from one generation to the next though still reflecting variations and thus different cuisines within the town. The epistemological dimension extends well beyond cooking skills; as laid out above, a range of different, everyday activities would form the basis for any meal before it reached the table. Third, the continued consumption of food types also implies a continued social situation in relationship to the meals: a re-creation and maintenance of social relations and interactions connected to food preparation and the meal itself. Lastly, it could be argued that a consistent, mixed diet likely reflects what we might expect from ordinary people in medieval Oslo: repeatedly making the same foods, which represent the embodied memory of past meals, and a preferred selection of familiar foods. This last issue leads to a discussion of agency and the level of individual choice, preferences, and an ability to influence a given situation. Demographic studies of health within the urban population based on osteological remains might further support a high level of individual agency: the Oslo population displays a relatively low presence of dietary deficiencies and malnutrition during childhood compared to other European medieval urban populations (Holck and Kvaal 2000; Jensen 2018).

\section{The Construction of the Self through Memory and Food-related Practices}

Turning back to the theoretical framework outlined initially, the individual dietary results from Oslo provide constructive tools for reflecting on the dynamics at play between society and the self in relation to food. This discussion is structured around three main themes: the construction of identity through memory 
and food-related practices; the negotiation between the self and society; and ultimately, the dynamics between political organization and individual human agency.

Bioarchaeological results can be used to learn more about these 20 specific individuals and the construction of the self by taking a closer look at individual consumption in relation to memory production: "Taste participates in the formation of the self and the creation of the group through shared preferences for certain foods and food combinations. This identity is personal, even though it is shaped by experiences within a cultural tradition” (Hastorf 2017, 30).

The Oslo population included a woman who died when she was approximately 60 years old (Naumann et al. 2019, Table 1), and radiocarbon dating of one of her teeth suggests that she was a child in the period AD 943-1024 (with $80 \%$ certainty), as ${ }^{14} \mathrm{C}$ values in teeth are conserved from the time of tooth formation (Sealy, Armstrong, and Schrire 1995). This testifies that she lived during the very first generations of urban settlement in Oslo, and probably through the first stages of urbanization process. We do not know whether she was born and raised in the area of the old town of Oslo - results from strontium analyses in her teeth are consistent with a person spending her childhood somewhere in the extended rural Oslo region, though the results are not conclusive; the values might also represent other geographical regions. Different strontium values in two teeth, representing two different periods during childhood, indicate that she moved during her childhood. What we do know for certain is that she was buried in Oslo during the first phases of urban settlement, and thus probably lived within the town or the extended settlement that was part of the urban community.

These details provide us with a range of information that can be linked to her memory production. She experienced a high degree of variation on many levels during her life, not only as a result of moving between different locations, but also through the urbanization process, which included settlement expansion and the ensuing impact on the dynamics between the rural area surrounding Oslo and the expanding town, and subsequent shifts in political structure. Also, she reached a significant age, at least compared to the contemporary life expectancies of her time, and arguably underwent different identities during various stages of her life.

In her ongoing process of memory production, how did she make active and unintentional choices to selectively remember - and selectively forget? While a vast array of her memory production is lost to us today, there are details that can be exposed through bioarchaeological material. The isotopic data reveals that she ate a combination of different foods, including a significant proportion of fish. The ${ }^{13} \mathrm{C}$ values, used as the most reliable indicator of individual dietary change (Lovell, Nelson, and Schwarcz 1986), suggest that no or very little change occurred in her dietary habits during her childhood, and also between childhood and the last years of life (Naumann et al. 2019). This information communicates a range of 
daily social practices that she engaged in, directly or indirectly, in relation to the procurement, preparation, and the consumption of food. For instance, the access to fish had to be constantly upheld throughout her life, from a young age, when those taking care of her made sure, by their own hand or via some form of exchange, that fish was a regular part of her diet, to later in life, when she may or may not have participated in acquiring the fish. The act of fishing and preparing fish involves a multitude of actions connected to the production and maintenance of equipment, access to and knowledge of fishing activities, and a command of proper preparation techniques for this particular food type. Without doubt, these actions and the very consumption of the meal involved a sensorial and emotional involvement deeply rooted in memory production through taste, smell, sight, sounds, and social interaction (Hastorf 2017). The repetitive actions would have actively produced and reproduced embodied memory that was maintained from her very early childhood to the end of her life. As food consumption is arguably tightly bound to identity production (Schrader 2019), the maintenance of foodrelated experiences should be understood as a constant reproduction of identity through the memory of a previous self.

Another individual from the Oslo population was a male likely born between $\mathrm{AD} 1028$ and 1184, representing a later generation of the urban inhabitants. He was approximately 60-70 years old at the time of death, and had, like the previously discussed woman, a diet consisting of both a substantial amount of land-based food as well as fish. The ${ }^{13} \mathrm{C}$-values show that his diet varied to a very limited extent, if at all. Strontium values suggest that he may have moved around during childhood, but high strontium values indicate that he likely resided in the Oslo region at least during his late childhood / adolescence. The strontium values do not allow for an identification of place of residence during the latter part of his life, but he was eventually buried in Oslo, having reached an advanced age. He does not seem to have undergone any dietary change in the course of his life, despite the fact that he probably did move around, at least as a child, indicating that he came from nearby, and that he moved within the Oslo region, possibly between different farms connected to the urban settlement and the town. The town expanded markedly during this time period, accompanied by an increase in political and religious regulations. Even so, this individual likely continued the eating habits established in his earliest childhood until the end of his life.

\section{The Negotiation between the Self and Society}

In the case of the analyzed individuals from Oslo, then, there emerges an identity that is representative for the collective, a communal form of identity, by 
nature more fixed and constant than the dynamic form of identity often observed at an individual level (Meskell 2001; Gardner 2011). This argument is based on the observation that the repetitive experience regarding eating habits was true for most people within this study, and thus the repetition of foodrelated activities was essential in identity production, contributing to an overarching, collective identity shared by a group of people over several generations.

Even though individuals reconstructed food-related activities and identities through memory production, there is dietary variation between the analyzed individuals - that is, these 20 people had fundamentally different food-related experiences - but those experiences appear to have been consistent throughout the individuals' lives. This long-term consistency of habits provides a concrete example of group identity that undoubtedly defined a separation between "us" and "them" - individuals defining themselves as belonging to a certain group (for instance, to a specific family) through the fellowship of shared everyday practices in food procurement, preparation, and consumption. Given that most individuals in this study arguably upheld a fixed element of identity through the maintenance of food-related experience, the very continuation of communal identity construction might be considered in relation to power negotiations between the self and society. This communal identity can possibly also be relevant for discussing levels of human agency and the ability to influence one's living conditions within an early and expanding urban environment.

\section{The Dynamics between Political Organization and Individual Human Agency}

What then is the relationship between this communal and fixed identity construction and general power relations and individual agency in the early urban community of Oslo? Returning to the conclusions about human food preferences drawn by Paul Rozin (1976), it seems relevant to dwell for a moment on the foodstuffs available in early medieval Oslo, and what food was actually consumed. As previously mentioned, although many details regarding individual consumption are lost to us, we can still draw some general conclusions about individual diet among the 20 analyzed individuals. We know from the faunal remains that a number of animals and marine species were exploited and thus available for the town's population (Øye 1998; Hufthammer 2015). Furthermore, the isotopic results indicate that all 20 individuals consumed a varied diet, most of them eating a combination of foods from land and sea, and none of them eating exclusively 
marine foods or plants. It thus seems most likely that a varied diet is more likely to be the preferred diet of most people, both from an anthropological and a nutritional perspective, rather than a consistent diet with little variation. This conclusion is further supported by previous results from osteological analyses (Holck and Kvaal 2000; Jensen 2018), suggesting that the urban population suffered relatively little malnutrition. Also, as people are generally conservative in food selection, with a general skepticism about trying new and unfamiliar foods (Rozin 1976), the dietary consistency should be understood as an active and preferred individual choice rather than an involuntary and forced activity. Last, but not least, the overall consistent food habits of this pool of people occurred during a period of Christianization, a process that is documented to have involved strong political efforts to impose regulations on the general population, prohibiting certain types of meat that were previously consumed, and imposing several fasting days during the cycle of the year. This suggests that people actively resisted the restrictions and regulations concerning their everyday dietary habits. Thus, although a combination of change in eating regimens as well as malnutrition could have been the expected result of imposed and involuntary dietary regulations, the bioarchaeological results from early medieval Oslo indicate that during a period of expansion, Christianization, and increased political presence, there was a high level of human agency, as evidenced by dietary consistency and adequate nutrition.

In conclusion, I would like to propose two possible explanations for the nutritional stability of this population: 1) during the early phase of urbanization, a centralized authority wielded little control over the population, and/or 2) the political organization of urban expansion in Oslo's earliest phases permitted some level of individual agency in terms of individual living conditions, thus allowing for consistency in daily food-related practices. Either way, it can be argued that food-related experiences should be considered in close relation to identity construction and active memory production. These experiences contributed to the forming of overarching and fixed group identities that shaped the self and society in early medieval Oslo. Food practice in medieval Oslo played an essential part in the negotiation and establishment of the self, and of social identity as part of individual memory.

During periods of religious, political, and organizational change within the expanding urban settlement of medieval Oslo, multiple generations maintained a continuity of food practices related to food procurement, preparation, and the meal itself, which then contributed to a maintenance of cultural identity. 
Acknowledgements: I would like to thank the editorial board for inviting me to contribute to this book, and also for thorough feedback and interesting discussions during the process. I am also grateful to Zanette Glørstad, Paul Fullagar, Martine Petlund Breiby, and Ryan Mills for a fruitful collaboration on the Clemens human material, and to Hege Vatnaland for providing the illustration in Fig. 1. Additionally, I would like to thank Kathryn Boyer for a through copyediting of the text, and two referees for valuable feedback on the manuscript.

\section{References}

Appadurai, Arjun. 1986. "Introduction: commodities and the politics of value". In The social life of things. Commodities in cultural perspectives. Ed. A. Appadurai. Cambridge University Press.

Barker, Lewis M. 1982. "Building Memories for Foods." In The Phychobiology of Human Food Selection. Ed. Lewis M. Barker. Chichester. 85-99.

Bukkemoen, Grethe Bjørkan. 2016. "Cooking and Feasting: Changes in Food Practice in the Iron Age." In The Agrarian Life of the North 2000 BC-AD 1000. Studies in Rural Settlement and Farming in Norway. Ed. Frode Iversen and Håkan Petersson. Oslo. 117-31.

Chisholm, Brian S., D. Erle Nelson, and Henry P. Schwarcz. 1982. "Stable-carbon Isotope Ratios as Measure of Marine Versus Terrestrial Protein in Ancient Diets.” Science 216: 1131-32.

Cipolla, Craig N. 2008. "Signs of Identity, Signs of Memory." Archaeological dialogues 15: 196-215.

Douglas, Mary and Baron Isherwood. 1996. The World of Goods: Towards an Anthropology of Consumption. 2nd ed. New York.

Dybdahl, Audun, 2000. Osteologisk materiale som historisk kilde. Trondheim.

Eide, Ole Egil. 1974. De toskipede kirker i Oslo. Et forsøk på å redatere og opphavsbestemme med utgangspunkt i de siste utgravninger i Clemenskirken. Bergen.

Gardner, Andrew. 2011. "Paradox and Praxis in the Archaeology of Identity." In Identity Crisis: Archaeological Perspectives on Social Identity. Ed. Lindsay Amundsen-Meyer, Nicole Engel, and Sean Pickering. Calgary. 11-26.

Goody, Jack. 1982. Cooking, Cuisine and Class. Themes in Social Sciences. Cambridge. Griffin, Kersin. 1988. "Plant Remains." In "Mindets tomt" - "Søndre felt”: Animal Bones, Moss, Plant-, Insect- and Parasite Remains. Ed. Erik Schia. De arkeologiske utgravninger i Gamlebyen, Oslo, 5. Øvre Ervik. 15-108.

Halbwachs, Maurice. 1992. On Collective Memory. Chicago.

Hamilakis, Yannis. 2011. "Archaeology of the Senses." In The Oxford Handbook of the Archaeology of Ritual and Religion. Ed. Timothy Insoll. Oxford. 208-25.

Hastorf, Christine A. 2017. The Social Archaeology of Food. Cambridge.

Helle, Knut. 2006. “Del I: Fra opphavet til omkring 1500.” In Norsk byhistorie: Urbanisering gjennom 1300 år. Ed. Knut Helle, Finn-Einar Eliassen, Jan Eivind Myhre, and Ola Svein Stugu. Oslo. 23-142.

Holck, Per and Ingunn Kvaal. 2000. Skjelettene fra Clemenskirken i Oslo. Antropologiske skrifter, 6. Oslo. 
Holmsen, Andreas. Ødegårder i Osloherad.” St. Hallvard 41.7: 289-338.

Hufthammer, Anne Karin. 2015. "Rapport JS 1675. Follobanen - Gamlebyen F03,

'Arkeologigropa', Oslo k., Oslo. Ubrent materiale.” Bergen.

Jensen, Anne Østergaard. 2018. Osteologisk anlayse av skjelettmateriale fra Nikolaikirkens

kirkegård. Follobanen F04/Saxegaardsgata 15. NIKU Oppdragsrapport, 160/2016. Oslo.

Jones, Andrew. 2007. Memory and Material Culture. Cambridge.

Lévi-Strauss, Claude, 1966. “The Culinary Triangle.” Partisan Review 33: 586-96.

Lie, Rolf. 1979. “Osteologisk materiale fra 'Oslogate 7'." In Feltene "Oslogate 3 og 7”:

Bebyggelsesrester og funngrupper. Ed. Erik Schia. De arkeologiske utgravninger $\mathrm{i}$ Gamlebyen, Oslo, 2. Øvre Ervik. 108-23.

Lovell, N. C., D. E. Nelson, and H. P. Schwarcz. 1986. "Carbon Isotope Ratios in Palaeodiet: Lack of Age or Sex Effect." Archaeometry 28: 51-5.

Lupton, Deborah. 1996. Food, the Body and the Self. London.

Martin, Debra L., Ryan P. Harrod, and Ventura R. Péres. 2013. Bioarchaeology: An Integrated Approach to Working with Human Remains. Manuals in Archaeological Method, Theory and Technique. New York.

Meskell, Lynn. 1999. Archaeologies of Social Life. Social archaeology. Oxford and Malden.

Meskell, Lynn. 2001. “Archaeology of Identity.” In Archaeological Theory Today. Ed. Ian Hodder. Cambridge. 187-213.

Molaug, Petter. "Oslo blir by.” In De første 200 årene - nytt blikk på 27 skandinaviske middelalderbyer. Ed. Hans Andersson, Gitte Hansen, and Ingvild Øye. Universitetet $\mathrm{i}$ Bergen Arkeologiske skrifter, Nordisk, 5. Bergen. 73-92.

Naumann, E., A. Z. T. Glørstad, M. P. Breiby, R. D. Mills and P. D. Fullagar. 2019. "Who Were the First Urban Settlers of Oslo? A Discussion of Early Medieval Urbanization Based on Isotopic Analyses of Human Remains." Archaeometry 61.5: 1111-28.

Naumann, Elise, Maja Krzewínska, Anders Götherström, and Gunilla Eriksson. 2014. "Slaves as Burial Gifts in Viking Age Norway? Evidence from Stable Isotope and Ancient DNA Analyses." Journal of Archaeological Science 41: 533-40.

Naumann, Elise, T. Douglas Price, and Michael P. Richards. 2014. "Changes in Dietary Practices and Social Organization during the Pivotal Late Iron Age Period in Norway (AD 550-1030): Isotope Analyses of Merovingian and Viking Age Human Remains." American Journal of Physical Anthropology 155: 322-31.

Nordeide, Sæbjørg Walaker. 2011. The Viking Age as a Period of Religious Transformation. Studies in Viking and Medieval Scandinavia, 2. Turnhout.

Nordeide, Sæbjørg Walaker and Steinar Gulliksen. 2007. "First Generation Christians, Second Generation Radiocarbon Dates: The Cemetery at St. Clement's in Oslo.” Norwegian Archaeological Review 40: 1-25.

Norseng, Per G. 2015. “Middelalderbyen Oslo og fiskeressursene i Indre Oslofjord.” In En aktivist for middelalderbyen Oslo: Festskrift for Petter B. Molaug i anledning hans 70-årsdag 19. desember 2014. Ed. Lise-Marie Bye Johansen, Egil Lindhart Bauer, Jan Brendalsmo, and Knut Paasche. Oslo. 189-242.

Pearson, Jessica and Lynn Meskell. 2015. "Isotopes and Images: Fleshing out Bodies at Çatalhöyük." Journal of Archaeological Method and Theory, 22: 461-82.

Pollard, A. M. and C. Heron. 2008. Archaeological Chemistry. Cambridge.

Rozin, Paul. 1976. "The Selection of Food by Rats, Humans, and Other Animals." In Advances in the Study of Behavior, 6. Ed. Jay S. Rosenblatt, Robert A. Hinde, Colin Beer, and Evelyn Shaw. New York. 21-76. 
Rozin, Paul. 1987. "Psychobiological Perspectives on Food Preferences and Avoidances." In Food and Evolution: Toward a Theory of Human Food Habits. Ed. Marvin Harris and Eric B. Ross. Philadelphia. 181-206.

Schia, Erik. 1991. Oslo innerst i Vika. Aschehoug. Oslo.

Schrader, Sarah. 2019. Activity, Diet and Social Practice: Adressing Everyday Life in Human Skeletal Remains. Bioarchaeology and Social Theory. Cham.

Sealy, Judith, Richard Armstrong, and Carmel Schrire. 1995. "Beyond Lifetime Averages: Tracing Life Histories through Isotopic Analysis of Different Calcified Tissues from Archaeological Human Skeletons." Antiquity 69: 290-300.

Skaar, Rebekka Alette. 2014. "Matkultur i norsk middelalder: Drep meg konge, men ikke med graut!" Unpublished M.A. thesis, University of Oslo.

Sture, Maria and Egil L. Bauer. 2017. "Heilag graut, franse hagar og barn døypt i øl: Skrift, arkeologi og botanikk som kjelder til matkultur i mellomalderen.” Primitive tider 19: 43-60.

van der Sluis, L. G., H. I. Hollund, H. Kars, P. U. Sandvik, and S. D. Denham. 2016.

"A Paleodietary Investigation of a Multi-period Churchyard in Stavanger, Norway, Using Both Stable Isotopes (C, N, H, S) on Bone Collagen." Journal of Archaeological Science Reports 9: 120-33.

Van Dyke, Ruth M. and Susan E. Alcock. 2003. "Archaeologies of Memory: An Introduction.” In Archaeologies of Memory. Ed. Ruth M. Van Dyke and Susan E. Alcock. Malden. 1-13.

Vedeler, Marianne. 2017. “Fra kokebøker til matrester i middelalderbyen.” Primitive tider 19: 61-78.

White, Tim D., Michael T. Black, and Pieter A. Folkens, eds. 2012. Human Osteology. 3rd ed. Amsterdam.

Øye, Ingvild. 1998. Middelalderbyens agrare trekk. Bergen. 


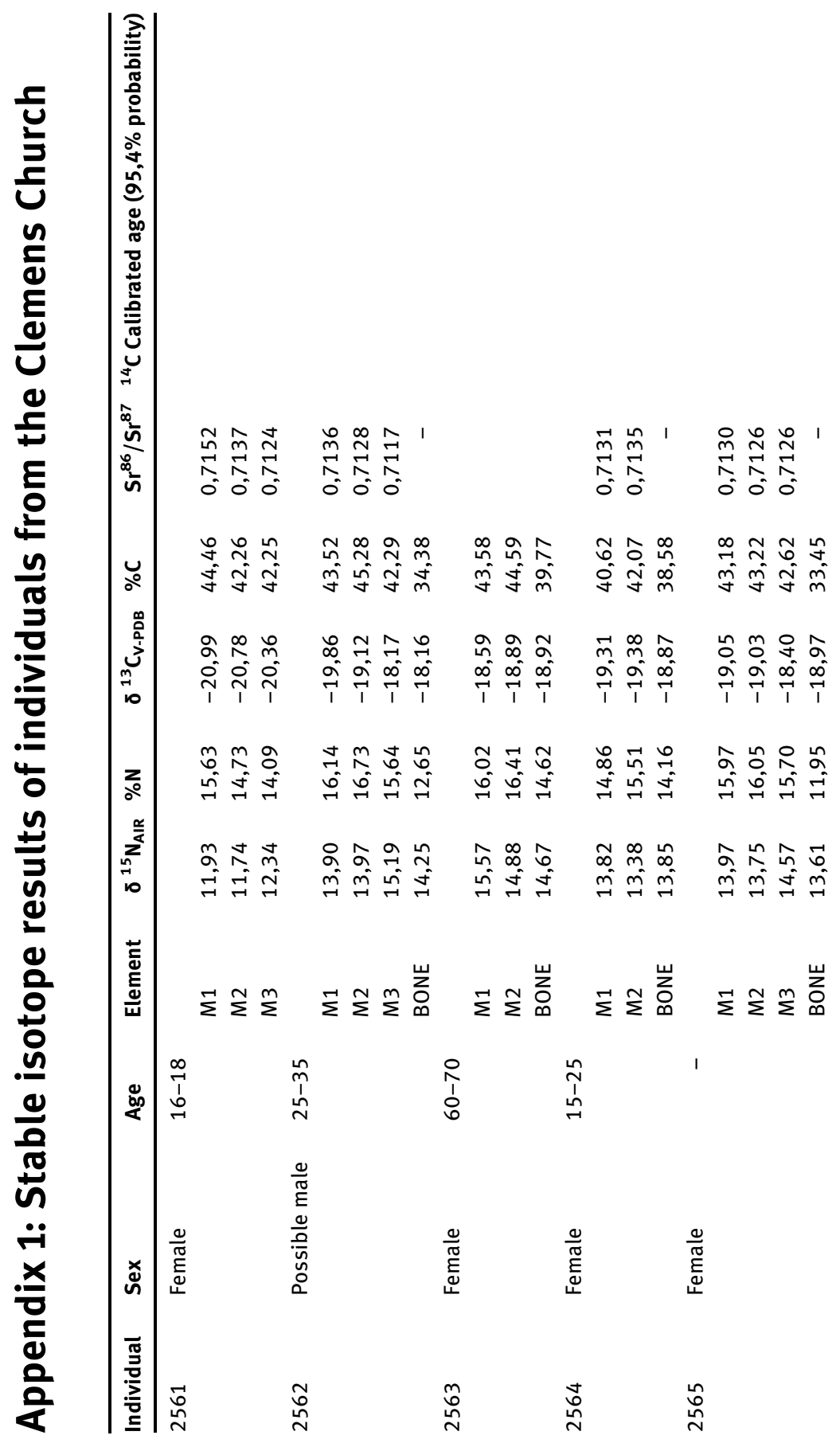




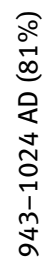

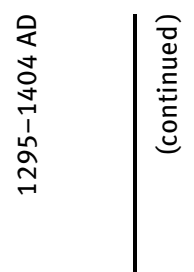

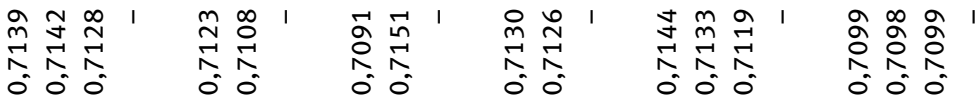

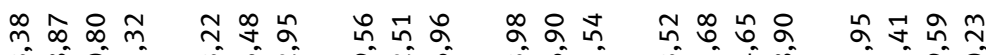
ले की

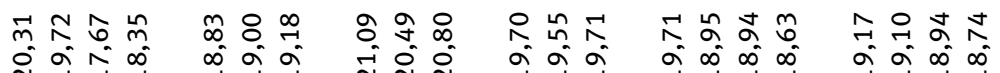
仓े

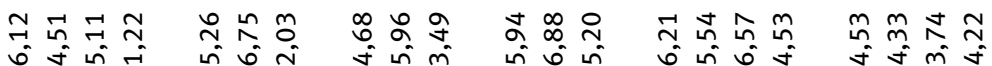

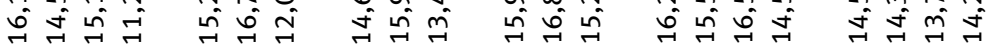

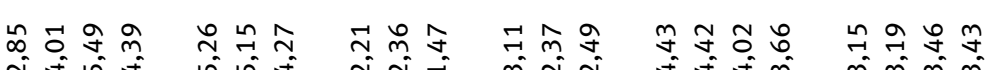


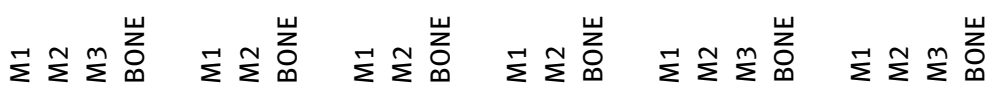
$\stackrel{\stackrel{n}{\sim}}{\stackrel{n}{\sim}}$ 응

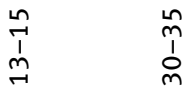

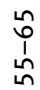

$\frac{\oplus}{\sqrt[\pi]{0}}$

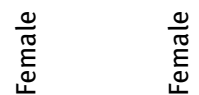

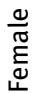

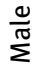

$\frac{0}{20}$

$\stackrel{\circ}{\stackrel{\circ}{N}}$

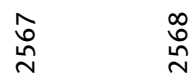

$\stackrel{a}{\stackrel{0}{n}}$

$\stackrel{\circ}{\stackrel{2}{\sim}}$

$\stackrel{m}{n}$ 


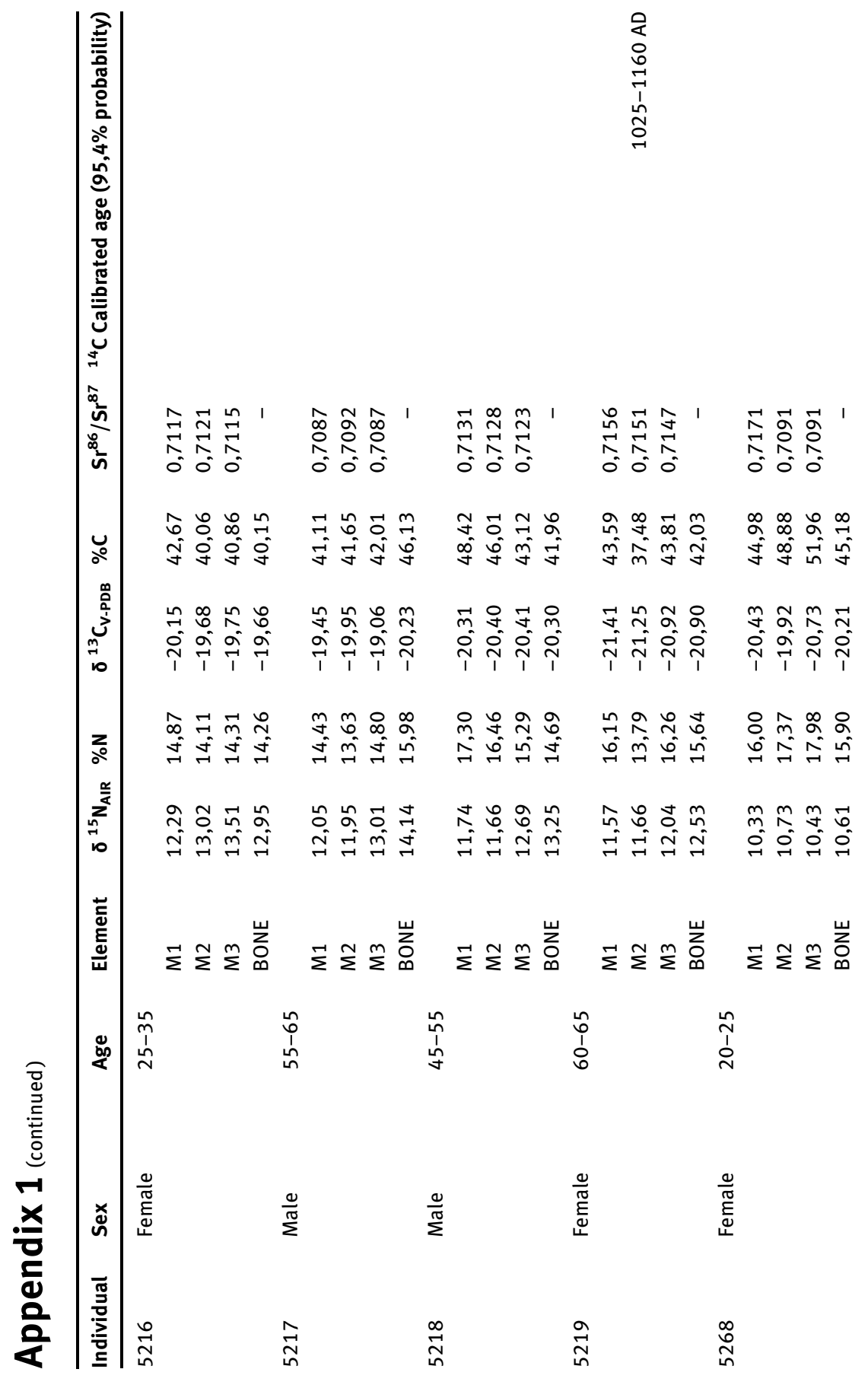




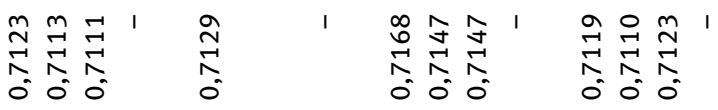

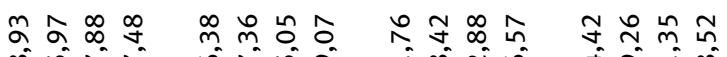

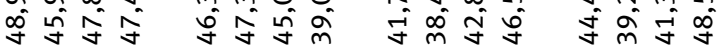

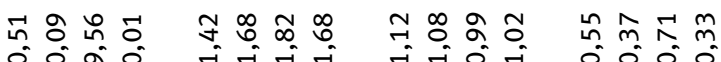
iิ

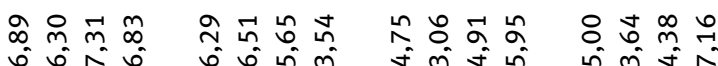

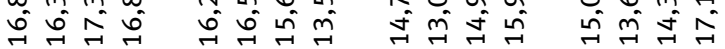

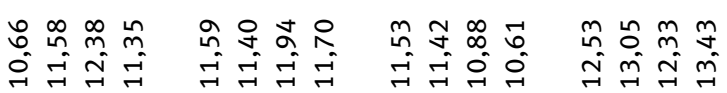

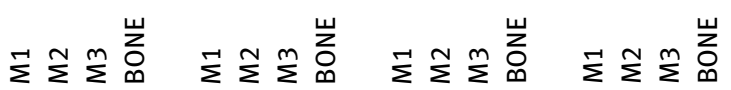

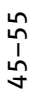
운
1
o ํㅜㄹ

웅

$\frac{0}{20}$

$\frac{\sum}{3}$

莺

$\frac{0}{20}$

ํํำ

กิ

กิ

กิ 
